\title{
THE ROLE OF FAULT AND POLICY IN NEGLIGENCE LAW
}

\author{
LEWIS N. KLAR*
}

The article describes how the developments of Canadian negligence law have extended it beyond its conceptual limits. The author discusses how the courts have gradually shifted the purposes of the negligence action towards achieving loss distribution by liability insurance, compensating the injured and disabled, deterring tortious conduct, and other public and social policy goals, which he suggests should instead merely remain the consequences of the tort action, and not its primary purposes. Instead, suggests the author, the courts have increasingly failed to recognize negligence law's traditional purposes of apportioning moral blame, sanctioning tortious conduct, and correcting wrongs.

Absent its fundamental premise of fault, the author maintains that negligence law is merely an inefficient and expensive way to provide for the needs of accident victims, which could be better and more efficiently dealt with by legislative intervention. Further, the author submits that as tort law becomes seen more as a means to compensate, deter, punish and educate, and less as a vehicle for corrective justice, the elements of the negligence action will lose their importance. Instead, he suggests that the judiciary must re-focus tort law as a system of fault-based correctivt justice, supplemented by programs designed to efficiently achieve compensation, punishment, deterrence, accident prevention, and other public policy goals. In discussing these issues, the author provides an extensive review of the leading and relevant cases and authorities in this area.
Le présent article décrit comment, au fil de son évolution, le droit de la négligence est allé au-delà de ses limites conceptuelles. L'auteur montre comment les tribunaux ont graduellement modifié les objectifs des actions fondées sur la négligence en vue de réaliser une ventilation des pertes par l'assurance responsabilité, l'indemnisation des victimes, l'élimination des comportements délictueux, et d'autres objectifs publics et de politique sociale - qui devraient, d'après lui, rester des conséquences des actions fondées sur la négligence et non pas en supplanter les objectifs premiers. Selon l'auteur, les tribunaux ignorent ainsi les objectifs traditionnels de cette branche du droit - attribution du blâme, sanction des actes délictuels et redressement des torts.

Sans la prémisse fondamentale de la faute, l'auteur soutient que le droit de la négligence offre simplement des solutions inefficaces et onéreuses aux problèmes des accidentés. De plus en plus, à mesure que le recours en responsabilité délictuelle tend à ètre perç comme un moyen d'indemnisation, de punition et d'éducation, plutôt que comme un véhicule de mesures rectificatrices, les éléments des actions fondées sur la négligence perdent de leur importance. L 'appareil judiciaire doit donc faire du droit de la négligence un système de redressement fondé sur la faute, auquel viendront s'ajouter des programmes d'indemnisation, de sanctions, de dissuasion, de prévention des accidents, et visant $\dot{a}$ réaliser d'autres objectifs d'ordre public. L'auteur fait état de nombreuses causes pertinentes, ainsi que du point de vue de spécialistes sur la question.

\section{TABLE OF CONTENTS}

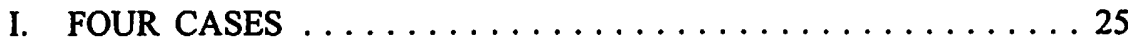

II. THE GROWTH OF THE NEGLIGENCE ACTION $\ldots \ldots \ldots 27$

III. THE ROLE OF FAULT AND POLICY

IN NEGLIGENCE LAW ................. 29

A. THE DUTY OF CARE ISSUE $\ldots \ldots \ldots \ldots \ldots \ldots \ldots \ldots$

B. THE BREACH OF DUTY ISSUE $\ldots \ldots \ldots \ldots \ldots \ldots \ldots 38$

C. THE ISSUE OF CAUSE $\ldots \ldots \ldots \ldots \ldots \ldots \ldots \ldots \ldots$

D. THE DEFENCES $\ldots \ldots \ldots \ldots \ldots \ldots \ldots \ldots \ldots \ldots \ldots$

IV. PURE ECONOMIC LOSSES $\ldots \ldots \ldots \ldots \ldots \ldots \ldots \ldots \ldots$

Associate Dean, Faculty of Law. Portions of this article were first presented to a Personal Injury symposium organized by the Legal Education Society of Alberta, in Banff, Alberta, 1995. 


\section{FOUR CASES}

A. On October 3, 1988, John Stein, aged seventeen, was playing in a minor hockey league game, when he crashed head first into the boards, fractured his spine, and became a quadriplegic. The accident occurred because the ice beneath Stein's skates cracked and developed a hole. This tripped Stein and sent him into the boards. It was found that the hole developed because the ice in that area was too thin. It was only about $1 / 2$ inch thick; the "acceptable" thickness was about 1 inch to $11 / 2$ inches. John Stein sued the municipality which owned the arena and the employees who were responsible for the ice-maintenance, in negligence. The defendants argued that there was insufficient evidence as to the thickness of the ice, and as to the cause of the fall. They presented other theories. The trial judge held that the plaintiff had proved his case and awarded him nearly $\$ 9.0$ million in damages. The judgment was upheld on appeal. The Court of Appeal conceded that the trial judge had taken a "robust and pragmatic approach" to the facts of the case.

B. On July 1986 two young men, Vince and Jean, went out for a night of drinking. They went in Jean's souped-up muscle car. They both got drunk. In the early morning hours, they drove along a gravelled road and their car stalled. They could not find the ignition key, and thus decided to attempt to roll start the car. Vince did the driving. He started the car but lost control of it. It went into a ditch and Vince was injured. Vince sued Jean alleging negligence in Jean's acquiescing to his driving. Vince won his case, and he was awarded 50 percent of his damages from his friend Jean. ${ }^{2}$

C. A barge was being towed down the Fraser River by two tugs when it struck a railway bridge owned by the Crown. As a result of damage to the bridge, the Canadian National Railway lost the use of the bridge and suffered economic losses. The CNR sued the owners of the tugs in negligence.

In deciding whether the defendant should be found liable to the plaintiff in this type of negligence action, one of the Supreme Court of Canada Justices addressed the idea that for certain types of claims, liability should be based not in terms of fault, but in terms of economic considerations. In this respect, there are several economic arguments. The "insurance theory," for example, suggests that the person who is in a better position to predict the economic losses consequent on an accident and hence to obtain cheap insurance against the contingency, should bear the loss. The "loss spreading theory" assumes that for certain types of losses it is better for the economic well-being of society to spread the risk among many parties rather than to place it on the shoulders of one, and thus that the better "loss spreader" should bear the loss. The "contractual allocation of risk theory" suggests that the law of negligence should not compensate those plaintiffs who are in a position to contractually allocate the risks of loss in advance. The learned Justice after considering these arguments rejected them. Based on 
the proximate relationship of the parties and the lack of policy concerns to negate or limit a duty of care, the Justice found for the plaintiff. ${ }^{3}$

A second Justice in the case, however, was more impressed with the economic arguments. Indeed, the Justice opined that "liability in this particular area should not be established based on the court's perception of the extent of the defendant's moral fault." Furthermore, "cases like the present do not fall to be decided on the grounds of personal fault. Rather they concern the effort to deter accidents and to allocate losses in a reasonable and efficient manner." ${ }^{5}$ In deciding issues of liability in such cases, it is important to consider not only the position of the defendant, but the plaintiff's position as well. Since accident avoidance is not the primary issue, ${ }^{6}$ loss bearing ability can come to the forefront. That being the case, the issue of insurance, in terms of both its availability and its cost, must become an overt consideration. This being so, "it would behoove lawyers ... to inform themselves about fundamental matters of insurability in new tort cases and to see to it that courts are also informed...." ${ }^{17}$ The Justice found that in view of the CNR's "overwhelmingly superior risk-bearing capacity," recovery should be denied. ${ }^{8}$

D. Two employees of the defendant's storage company negligently dropped an expensive piece of equipment belonging to the plaintiff. The owner of the damaged item sued the storage company and its employees. The majority of the Supreme Court found that the employees owed a duty of care to the owner which they breached. There was therefore liability. However, by extending a limitation of liability clause contained in the storage contract, the Court was able to limit the employees' liability.

There was one forceful dissent. Pursuing the line of argument which he had articulated in the C.N.R. case, La Forest J. argued that economic theory is relevant not only in pure economic loss cases, but in property damage cases as well. In determining liability, "courts must be sensitive to the impact that an imposition of tort law would have on the contractual allocation of risk, whether the damage incurred is economic loss or property damage." 9 La Forest J. applied economic theory to the issue of an employee's personal tort liability in a case such as this. He argued that allowing an employee to be personally sued for negligence undermines the policies behind holding

C.N.R v. Norsk Pacific Steamship Co. (1992), 11 C.C.L.T. (2d) 1, McLachlin J. thereinafter C.N.R.].

Ibid. at 105, La Forest J.

$3 \quad$ lbid.

6 The argument is that deterrence and accident avoidance concerns will already be taken care of since the wrongdoer will still remain liable to the direct victims of its negligence even if it is relieved of liability to the indirect victims. Where, as in personal injury or property damage cases, the issue is whether there will be any liability at all, the argument is that accident avoidance by means of the internalization of accident costs should take precedence over the issue as to who is the better loss bearer.

, C.N.R, supra note 3 at 111 , La Forest J.

$8 \quad$ Ibid. at 112.

9 London Drugs v. Kuehne \& Nagel (1992), 97 D.L.R. (4th) 261 at 272-273 thereinafter London Drugs]. 
the employer vicariously liable in the first place. ${ }^{10}$ Moreover, it is inconsistent with the expectations of the parties when they are operating within a "planned" transaction, i.e. where the parties are in a position to allocate or otherwise deal with risks of loss in advance. After an extensive review of the case law and academic commentaries, La Forest J. eliminated the employee's personal tort liability to those suffering property damage where there was no reliance by the plaintiff on the employee and where the tort was committed in the context of a contractual relationship which the plaintiff had with the employer. ${ }^{11}$

\section{THE GROWTH OF THE NEGLIGENCE ACTION}

The above "four cases" amply validate the observation that Canadian negligence law has changed dramatically since 1921 . This will come as no surprise to anyone. One would be rightly astonished if this were not so. In 1921, the English common law world had not yet even heard of Mrs. May Donoghue. In fact, it would take another seven years before Mrs. Donoghue would drink the glass of ginger beer that would change the course of the modern law of torts. ${ }^{12}$

Certainly the most dramatic developments in Canadian tort law since 1921 have occurred in the expansion of the rights of plaintiffs in personal injury cases. Donoghue v. Stevenson marked the end of an era in which the law was decidedly pro-defendant, where even victims of personal injuries caused by the negligence of others could find their claims for compensation defeated by the doctrine of privity of contract, tort immunities, guest passenger restrictions, or other complete bars such as the defences of contributory negligence or voluntary assumption of risk. Over the next several decades courts and legislatures would act to restrict or eliminate in their entirety these anti-plaintiff doctrines. By 1996, most immunities from suit, such as spousal or governmental tort immunity, have been statutorily abrogated, the contributory negligence bar has given way to apportionment, guest passenger discrimination has been abolished, and the absolute defence of voluntary assumption of risk is on its death-bed.

A manufacturer's potential liability for bad ginger beer has exposed a host of careless actors to tort law's scrutiny. One could validate, with reference to numerous illustrations, Lord Buckmaster's prophetic warning that if the common law took the one step requested for by Mrs. Donoghue, there would be nothing to stop it from being

to Such as placing the risk of loss on the party who stands to profit from the activity, on the party who is in the best position to distribute the loss, and on the party who is in the best position to deter the accident. This is the employer, not the employee.

London Drugs, supra note 9.

For wonderful historical accounts of the famous episode which formed the basis of the English House of Lord's judgment in Donoghue v. Stevenson, [1932] A.C. 562 (H.L.) see Mr. Justice Martin R. Taylor's and Professor William McBryde's chapters in P.T. Burns \& S.J. Lyons, eds., Donoghue v. Stevenson and the Modern Law of Negligence, The Paisley Papers (Vancouver: The Continuing Legal Education Society of British Columbia, 1991). 
required to take another fifty. ${ }^{13}$ For example, In 1996 , not only must I drive my car safely, but I must make sure that I do not allow a careless or incompetent driver to borrow it. ${ }^{14}$ I must ensure that my young passenger is wearing his seat-belt, even if the child's father is in the car with us, and does not require that child to buckle up. ${ }^{15}$ My local pub owner must see to it that after I have spent an evening out at his establishment, I get home safely and avoid injury to myself or others. ${ }^{16} \mathrm{My}$ doctor must not only administer to my illness with all of the skill of the reasonably competent physician, but she also must see to it that I fully understand the nature and character of the treatment which she proposes for me, as well as all of its potential risks, and the alternative treatments which are available. ${ }^{17}$

It is of course true that the movement in terms of Canadian negligence law has not only been in the direction of growth; there have been significant set-backs. Two in particular stand out. In 1921, the process of removing tort law from workplace accidents was well underway, and by 1950 all Canadian provinces had no-fault workers' compensation programs in place. ${ }^{18}$ The result has been to bar tort claims whenever there exists a claim which is covered by the scheme. ${ }^{19}$ This bar has survived constitutional challenge, ${ }^{20}$ and despite considerable criticism, it is unlikely that tort law will ever regain this lost territory. Automobile accident compensation by means of tort also has been seriously compromised by no-fault schemes. Two Canadian provinces have totally eliminated tort from the automobile accident arena, ${ }^{21}$ and two others have adopted modified schemes which establish thresholds, and thus have the effect of removing the tort action from most automobile accident victims. ${ }^{22}$ Although many lawyers and others, including this writer, oppose this trend, it is very likely that the

"There can be no special duty attaching to the manufacture of food apart from that implied by contract or imposed by statute. If such a duty exists, it seems to me it must cover the construction of every article, and I cannot see any reason why it should not apply to the construction of a house. If one step, why not fifty?": Donoghue v. Stevenson, ibid. at 578. See e.g. Hall v. Hebert, supra note 2.

See Galaske v. O'Donnell, [1994] S.C.R. 670.

See Jordan House Ltd. v. Menow, [1974] S.C.R 239.

See Reibl v. Hughes, [1980] 2 S.C.R. 880.

See T.G. Ison, Workers' Compensation in Canada, 2d ed. (Toronto: Butterworths, 1985) at 1, n.1, for the dates of the respective provincial legislation.

Ibid. at 163.

See Piercey v. Gen. Bakeries Ltd. (1989), 56 D.L.R. (4th) 765 (S.C.C.).

In Manitoba, see Manitoba Public Insurance Corporation Act, S.M. 1993, c. 36, s. 5:

Notwithstanding the provisions of any other Act, compensation under this Part stands in lieu of all rights and remedies arising out of bodily injuries to which this Part applies and no action in that respect may be admitted before any court.

Subject to this Part, compensation is payable under this Part by the corporation, regardless of who is responsible for the accident.

In Quebec, see the Automobile Insurance Act, R.S.Q. 1977, c. A-25, as amended.

In Saskatchewan, see Automobile Accident Insurance Amendment Act, S.S. 1994, c. A-35, and in Ontario see Insurance Act, R.S.O. 1990, c. I.-8, s. 267.1(2), as enacted in the Insurance Law Amendment Act, S.O. 1993, c. 10. See discussion by K. Cooper-Stephenson, Personal Injury Damages in Canada, 2d ed. (Scarborough, Ont.: Carswell, 1994). 
economics of no-fault will rule the day ${ }^{23}$ and automobile no-fault will spread to other Provinces.

This author is a tort law enthusiast. I very much believe in the importance of the tort claim - the only real system of civil justice available to aggrieved individuals - to restore dignity to victims, to sanction wrongful conduct, to emphasize accountability and personal responsibility, and to ensure full compensation rights. Despite its defects, and in particular its high costs, no other legal mechanism exists anywhere which can accomplish these goals. Correcting wrongs by requiring personal responsibility and accountability still has a strong attraction. Thus, the growth of the 'neighbour principle' over the past century is a welcomed development.

The thesis of this article is that developments in Canadian negligence law over the past seventy-five years have extended it beyond its conceptual limits, and that ironically the success of tort threatens its survival in the twenty-first century. Negligence law is about wrongdoing. While this is admittedly an imprecise notion, there ought to be an element of moral blame in all conduct which tort law deems as negligent and hence liable for damages. The elements of the negligence action ought to conform and be interpreted by courts according to this notion of fault and the goal of correcting wrongs. Loss distribution by liability insurance, compensating the disabled, deterring wrongful conduct, regulating and educating professionals and industry, or achieving other public policy objectives, although frequently advanced through negligence law, ought to remain as the consequences of the tort action and not be seen as the purposes of the tort action. In this way, society can maintain a strong system of civil justice while recognizing the limitations to a system of civil justice. These limitations and gaps can then be best accommodated by non-tort schemes which are designed to accomplish these other objectives in an efficient and effective manner.

\section{THE ROLE OF FAULT AND POLICY IN NEGLIGENCE LAW}

When Lord Atkin and the House of Lords decided that Mrs. Donoghue's claim for damages was good in law, they did so for reasons of morality. They did not do so because they considered that it was economically efficient to hold the manufacturer liable. They did not regard liability insurance as a social welfare fund for the disabled. They did not wish to regulate the food and drug industry in Scotland. Lord Atkin's own words made his reason perfectly clear: "The liability for negligence, whether you style

This is not the place to debate the economics of tort and no fault. It is generally agreed that once the possibility of litigation is taken away from victims, the costs of administering the benefits to victims is less than the costs of tort. This argument overlooks many points; such as, the deterrent effect of tort law and the costs of accidents, and the level of benefits which are paid out in no fault as compared to torts. It is obvious that if insurance companies are given the power to collect the premiums at the levels which they wish, but control the level of benefits which they will have to pay out, they can keep costs down, and still make a lot of money. The argument also overlooks the non-economic issues; such as the dignity of the individual, the right to full compensation, the fairness in compensating both the wrongdoer and the victim equally, and the wisdom in selecting automobile accident victims out as a special group at all. 
it such or treat it as in other systems a species of 'culpa,' is no doubt based upon a general public sentiment of moral wrongdoing for which the offender must pay."24

Lord Atkin did not believe that immoral conduct inevitably resulted in legal liability, since "acts or omissions which any moral code would censure cannot in a practical world be treated so as to give a right to every person injured by them to demand relief,"25 but there is little doubt that on his view of negligence law liability could never arise in the absence of blameworthy conduct.

As has been so ably articulated by Professor Weinrib in his book and numerous articles on the theory of tort law, ${ }^{26}$ at its root tort law represents a system of corrective justice which remedies injuries caused to a victim by a wrongdoer. As explained by Weinrib, all elements of the negligence action - duty, breach, cause, and damage and the manner in which these elements are defined and established, are logical and explicable only by reference to tort's normative purpose. The duty of care is defined in terms of the defendant's ability to foresee injury to the plaintiff, as opposed to the world at large. The breach is defined in terms of the probability of the risk created with reference to the plaintiff, balanced by the remedial measures which could have been taken to avoid it. Cause is defined in reference to the fact that the plaintiff's injury would not have occurred had it not been for the defendant's act. Proximate cause is defined in terms of the defendant's ability to foresee the plaintiff's injuries. In other words, as Weinrib states, "tort law treats the two litigants as connected, one with the other, through an immediate personal interaction as doer and sufferer of the same harm. ${ }^{.127}$

Upon a finding of liability based upon fault, the remedy that tort law provides to right the wrong is full compensation - restoration of the status quo ante. This, as is well known, is frequently, although not necessarily, provided through liability insurance funds. That the defendant has pre-arranged the payment for damages caused by his or her fault in this way, in no way takes away from the essential nature of tort.

It is evident that compensating victims of accidents on the basis of fault has incidental consequences quite apart from tort law's main rationale as described above. First and foremost, a disabled victim is compensated. Where liability insurance is involved, this compensation may be effectuated without a crushing burden to the wrongdoer. This has a very strong appeal. An injured person, who probably does not carry insurance and who thus would otherwise have personally to bear a crushing loss

Supra note 12. Lord Atkin also stated, ibid. at 583:

I do not think so ill of our jurisprudence as to suppose that its principles are so remote from the ordinary needs of civilized society and the ordinary claims it makes upon its members Ibid. as to deny a legal remedy where there is so obviously a social wrong.

See E.J. Weinrib, The Idea of Private Law (Cambridge, MA: Harvard University Press, 1995); E.J. Weinrib, "Understanding Tort Law" (1989) 23 Valpraiso U.L. Rev. 485; E.J. Weinrib, "Two Conceptions of Tort Law" in R.F. Devlin, ed., Canadian Perspectives on Legal Theory (Toronto: Emond Montgomery Publications, 1991). 
can shift that loss to a defendant who will distribute it to others. Although the negligent conduct of the defendant and its causal connection to the loss are the pre-requisites to this mode of victim compensation and loss distribution, one can well understand how the incidental consequences of compensation and loss distribution can easily become to be seen as the principal purposes of tort. ${ }^{28}$ Thus, instead of tort law being described as a system of corrective justice, it begins to be seen and to be interpreted as a system whose primary purpose is to compensate accident victims.

Other incidental consequences of fault based compensation also can be identified. It can act as a deterrent with respect to wrongdoing and hence prevent accidents, it can educate actors, and it can punish wrongdoing. Thus, deterrence, accident prevention, and punishment become to be seen as tort law's purposes, and not, as they really are, the "sometimes" consequences of a tort judgment. Tort is soon no longer seen as an expression of a system of corrective justice, but as a vehicle through which other public policy goals can be achieved. Once these goals become more important than tort law's real essence, the requirements of duty, breach and cause become obstacles standing in the way of achieving these goals.

This article presents the argument that as tort law has become to be seen more as an instrument to compensate, deter, punish, and educate and less as an expression of a system of corrective justice, the elements of the negligence action have lost their relevance. While not denying the validity or utility of the incidental consequences of compensation based upon fault, I insist that it has been a mistake to transform these secondary consequences of tort into the primary purposes of tort. Not only does this undermine confidence in tort law itself, but it inefficiently achieves the consequences thought to be achieved by tort. A refocus on a system of corrective justice based upon fault, supplemented by programs designed to achieve in an efficient manner the public policy goals of compensation, punishment, deterrence and accident prevention would better serve society. The future of negligence law depends upon the judiciary's willingness to refocus on its essential element of fault.

\section{A. THE DUTY OF CARE ISSUE}

The neighbour test of Donoghue v. Stevenson was conceived of in terms of the "reasonable foreseeability" of harm to a victim in order to highlight the importance of fault and the interaction between injurer and victim which is the essence of tort. "Foreseeability," however, has become a meaningless concept in contemporary negligence law. In the vast majority of accident cases where a person has been injured, killed or has suffered property damage as the result of the act of another, a duty of care is found on the basis of proximity. In the rare case where a duty is denied, it is because for policy reasons the common law does not wish to compensate the plaintiff for his or her injury. It is, in other words, not foreseeability, but the desire to compensate or to withhold compensation, which drives the duty decision. 
Four interesting areas illustrate the duty issue and the importance of policy: the duty owed to rescuers, to suicide victims, to nervous shock victims, and the duty owed to protect and assist others. ${ }^{29}$

\section{The Foreseeability of Rescue}

In terms of "rescuers," a defendant who negligently imperils another person, or even $\mathrm{him} /$ herself, will be liable to a rescuer who in seeking to help the victim, becomes injured. The argument is that a rescue is a reasonably foreseeable consequence of an accident. In terms of policy, rescues are highly valued activities. The argument that rescuers willingly assume the risks of injury implicit in dangerous rescues is discounted by the theory that danger invites rescue, and that there is therefore no voluntariness involved. One can be skeptical about this. It is only tenuously arguable that it is within the reasonably foreseeable contemplation of a wrongdoer that rescuers will be imperilled by his or her negligent act. It is rather the desire to compensate and encourage rescuers which lies at the heart of this affirmative duty decision.

The leading case is Horsley v. MacLaren.$^{30}$ In this case, the captain of a pleasure boat was held to owe a duty of care to rescuers who jumped into the water to save a passenger who fell overboard. Another Supreme Court of Canada case on this issue is Corothers v. Slobodian. ${ }^{31}$ The plaintiff stopped her car at the scene of a traffic accident along a highway. She saw that there were injured people who needed help. She ran along the side of the highway gesticulating for help. A truck driver saw her running towards him, put on his brakes, the truck jack-knifed, went into a ditch, and hit the plaintiff. The Supreme Court allowed the plaintiff's negligence action against the individual whose negligence caused the first accident. The conduct of and injury to the "rescuer" was held to be a reasonably foreseeable consequence of the initial actor's negligence. In a more recent case, Schlink v. Blackburn, ${ }^{32}$ the plaintiff was home in bed when he heard that his wife had been in a car accident. While rushing to the scene of the accident, he fell down the stairs and broke a bone in his foot. The trial judge held that this was "foreseeable" and held the negligent party who injured the wife liable. The Court of Appeal reversed, holding that the plaintiff was not a "rescuer" and that there was no duty owed to him.

Two "rescue" cases in particular illustrate my concern that the goal of compensation has overtaken Lord Atkin's neighbour principle. The first is Urbanski v. Patel. ${ }^{33}$ The plaintiff father donated his kidney to his daughter. She had lost her only functioning kidney as a result of the defendant doctor's negligence. The foreseeability principle underlying the rescue cases was used as the basis of holding that the patient's father

The duty owed re: nervous shock, suicide, and rescue can equally be cast as a "remoteness" issue. That is, rather than asking whether the victim was foreseeable (duty), one can ask whether the injury was foreseeable (remoteness). For the sake of the discussion in this article, this categorization question has no importance.

(1972), 22 D.L.R. (3d) 545.

(1975), 51 D.L.R. (3d) 1 (S.C.C.).

[1992] 4 W.W.R. 251 (B.C.S.C.), rev'd (1993), 10 C.C.L.T. (2d) 173 (B.C.C.A.).

(1978), 84 D.L.R. (3d) 650 (Man. Q.B.). 
was a foreseeable victim of her doctor's negligence. According to the Court, since kidney transplantation is considered an expected and anticipated result for a person whose own kidneys are lost, it would be entirely "foreseeable" that a family member would agree to give up one of their kidneys for the benefit of a relative who is in need of one. Even more bizarre is the Ontario Small Claims Court judgment in Turvey v. Wilkins. ${ }^{34}$ In this case, a drunk owner of a truck appropriately asked his sober friend to drive him home. Unfortunately his friend drove negligently and damaged the truck. The owner of the truck sued his friend for damages to the truck only to be met with the rescue argument. The Court accepted the contention that the driver of the truck was "rescuing" the owner of the truck at the time of the accident by driving him home. The accident and the obligation of the driver to pay damages caused by his own negligent driving was seen as a foreseeable consequence of this "rescue," and part of the costs of the rescue, i.e. the damages which the "rescuer" was obligated to pay to the "rescuee," were shifted back to the rescuee.

\section{The Foreseeability of Suicide}

Contrast the law's attitude to rescuers with its attitude to suicide victims. Unlike rescue, suicide is not a valued activity. In fact, the law traditionally has been very harsh with respect to suicide. ${ }^{35}$ It is not surprising, therefore, to discover that unlike rescue, the law does not think that a suicide committed by a victim of an accident is a reasonably foreseeable and hence compensatable injury. Thus, unless the injury suffered by the victim is a psychological or mental disturbance which can be directly traced to the decision to commit suicide, the suicide will be considered to be too remote and not compensatable. In its creativity, the law distinguishes between "sane" and "insane" suicide victims. There is no liability for a suicide deliberately undertaken by a sane victim. However, someone who has become insane because of an accident and who commits suicide as a result, can recover.

In Wright Estate v. Davidson, ${ }^{36}$ the plaintiff was injured in a motor vehicle accident caused by the defendant's negligence. She suffered a serious "whiplash." She had never before suffered from emotional or mental problems. Nine months after the accident she committed suicide. Psychiatric evidence suggested that the suicide appeared to be the result of depression and apprehension from an inability to function normally. Her dependants sued the negligent motorist. The trial judge held that there was a direct causal link between the accident and the suicide and found in the plaintiffs' favour. The Court of Appeal reversed the judgment. Legg J.A. held that where the deceased's decision to commit suicide was "a conscious decision, there being no evidence of disabling mental illness ... her suicide must be taken as a novus actus interveniens such that it cannot be said that her death was a reasonably foreseeable consequence of the wrongdoing. ${ }^{\text {"37 }}$ 
Compare this case with the subsequent B.C. case of Costello v. Blakeson. ${ }^{38}$ There again the plaintiff was injured in a motor vehicle accident caused by the defendant's negligence. She suffered soft tissue injuries. Some two years after the accident she unsuccessfully attempted suicide by leaping from a second storey window. She suffered permanent serious injuries in the fall for which she sued the negligent motorist. The court found that prior to the motor vehicle accident the plaintiff suffered from emotional problems. She had even attempted suicide. She was an alcoholic. She had seizures. The trial judge distinguished her situation from that of the deceased in the Wright Estate case. Because the plaintiff in this case was suffering from a prior vulnerability and attempted suicide when she was under a mentally disabling condition, the "thin skull" rule was applied and the attempted suicide was found to be reasonably foreseeable.

One judgment even has gone so far as to hold that a doctor who negligently prescribed potentially lethal drugs to a known suicidal patient was not responsible for his suicide because the decision to commit suicide was the victim's personal responsibility. ${ }^{39}$ Or consider the following facts. The individual was injured in a motor vehicle accident, caused by the defendant's fault. The victim suffered a crush fracture of his right hip joint. This resulted in a period of "profound disability" followed by partial permanent disability. The pain associated with the injury was unrelenting and permanent. Relief could not be obtained through drugs or surgery. The victim's employment could not be continued. Before his suicide the victim was described by his psychiatrist as suffering from "neurotic depression caused by persistent pain, disability to pursue his regular life style and frustration at being unable to work remuneratively to support his family." 40 The court found that the patient was depressed and in genuine pain. Was his suicide reasonably foreseeable? No, it "was not an injury of the type nor of the extent which could have been foreseen." ${ }^{41}$ The claim of the dependents' failed. A judicial policy restricting compensation in cases of suicide dictated against recovery - lack of foreseeability was the justification.

\section{The Foreseeability of Nervous Shock}

The nervous shock jurisprudence has evolved significantly over the past seventy-five years. Similar to suicide, the common law traditionally has been suspicious and unfriendly to those who claim that they have suffered nervous shock as a result of another's negligence. Nevertheless, there has been a gradual inclination to accept nervous shock as a legitimate, compensable type of injury. Thus, we have now reached the point where nervous shock is said to be treated as just another type of personal injury, where compensation will be determined by the principle of foreseeability. ${ }^{42}$

[1993] 2 W.W.R. 562 (B.C.S.C.).

See Robson v. Ashworth (1986), 33 C.C.L.T. 229 (Ont. H.C.), aff d. (1988) 40 C.C.L.T. 164 (Ont. C.A.).

Swami v. Lo (1979), 11 C.C.L.T. 210 (B.C.S.C.).

Ibid. at 215.

See Haines J.'s judgment in Marshall v. Lionel Enterprises Inc., [1972] 2 O.R. 177 (Ont. H.C.J.) for a good review of the evolution of the case law. 
The nervous shock cases, however, also illustrate the importance of policy in the formulation of duty. While it is clearly foreseeable that a tragedy suffered by one person will lead to trauma and psychological injury suffered by relatives and bystanders, the policy concern of indeterminate liability has resulted in an arbitrary truncation of the negligent defendant's liability. Concepts such as "locational," "temporal," and "relational" proximity are used to rationalize decisions to confine a defendant's liability to those who were at the scene of the tragedy or who were there in its immediate aftermath, and were close relatives of the direct victims. As with suicide, one can see how a policy decision against the need to compensate has led to a denial of duty.

Two of the more interesting recent nervous shock cases are Rhodes Estate v. C.N.R..$^{43}$ and Alcock v. Chief Constable of the South Yorkshire Police. ${ }^{44}$ In Rhodes, the plaintiff's son was killed in the 1986 Hinton train tragedy. The plaintiff had taken her son to the train station in Vancouver, and heard about the crash on her car radio as she drove back to her home on Vancouver Island. She flew to Edmonton the next day, and then drove to Hinton to find out if her son had survived. It was only several days later that her worst fears were confirmed and the plaintiff discovered that her son had been killed. She suffered from extreme depression and psychiatric illness for a long time after the accident. The British Columbia Court of Appeal, reversing the trial court, struck out the plaintiff's Statement of Claim against the CNR. Wallace J.A. held that the plaintiff's illness was not reasonably foreseeable taking into account, among other things, the fact that she was not at the scene of the accident. The depression was linked more to the death of her son, as opposed to the traumatic accident itself. Other members of the Court noted that the law compensates only for "fright," "terror," or "horror," and not for depression, grief and sorrow.

The Alcock case concerned a major English soccer tragedy in 1989, in which ninetyfive people were killed and over 400 injured. Actions were brought for nervous shock suffered by numerous claimants, some of whom were in the stadium, one who was outside the stadium, and others who saw the scenes on television at home, or heard of it from friends, or through radio reports. In rejecting many of the claims, the House of Lords reaffirmed the need to impose limits on nervous shock recovery, based upon proximity factors, and based upon the need to establish that it is "shock" and not other emotions, such as sorrow, grief and depression as the basis of the plaintiffs' claims. ${ }^{45}$

\section{Liability for Nonfeasance}

One of the most interesting and instructive duty issues in contemporary law involves the duty to assist those in danger or to prevent persons from injuring themselves or others. This is highlighted by the recent Supreme Court of Canada judgments in Hall

$43 \quad$ (1990), 75 D.L.R. (4th) 248 (B.C.C.A.).

4 [1991] 1 All E.R. 533 (H.L.).

45 Other recent cases are Bechard v. Haliburton Estate (1991), 84 D.L.R. (4th) 668 (Ont. C.A.);

Strong v. Moon (1992), 13 C.C.L.T. (2d) 296 (B.C.S.C.); and Cox v. Fleming (1993), 13 C.C.L.T.

(2d) 305 (B.C.S.C.). 
v. Hebert ${ }^{46}$ and Stewart v. Pettie. ${ }^{47}$ As related above, Hall v. Hebert involved the duty imposed by the Supreme Court on an owner of a car which he owed to his drunk friend with respect to his friend's use of the car. Stewart v. Pettie involved the duty imposed by the Supreme Court on a commercial host owed to those who drink in their establishments and to third persons who are injured by patrons of drinking establishments. Both of these duties of care have been widely accepted as being reasonable and well within the mandate of negligence law.

In considering these cases and the duties which they have established, one should reflect on why the common law traditionally has refused to recognize a duty to rescue or otherwise to assist those in danger. As a system of corrective justice, tort law does not seek to distribute "wealth"48 by requiring reasonable or even moral conduct from those who are in a position to help or assist those in danger or in need. For example, one can idly sit by while by a baby drowns even where minimal effort would be required to save the infant. Tort law seeks only to restore victims to the position in which they would have been in had a wrongdoer not disturbed their status quo through his or her conduct. Since the status quo of a drowning infant is not altered by the inaction of a by-stander, a system of corrective justice has no role to play. Requiring a by-stander to help a drowning infant would be to require the by-stander to give something he has, i.e. the power to help, to the infant who needs it. The policy goal of redistributing wealth or requiring rescue is laudable, but is better achieved by legal regimes which are instrumentalist in nature, such as taxation systems, criminal, or even fiduciary law. Tort law is not such a regime.

Let me first consider the commercial host duty. When a court decides that a commercial host has a positive duty to assist an intoxicated patron or to prevent such person from harming himself or others, the law comes perilously close to the boundary between corrective and distributive justice.

What is the source of the commercial host's duty to prevent intoxicated patrons from injuring themselves or from injuring others? There are at least two possible answers to this question. The first, and one which frequently is given, is that due to the fact that a commercial host profits from the sale of liquor, there is a duty imposed upon the host to take reasonable care for the protection of those patrons and others who might be injured by them. This "profit" factor would thus distinguish the commercial host from the social host. This seems to me, however, to be a very unsatisfactory response. In tort, there is nothing inherently special about profiting from an activity. Thus, for example, a duty of care is owed both by a commercial and gratuitous driver of a car. Unless one rationalizes that it is part of the quid pro quo of the commercial transaction of selling liquor that due care will be taken of the customer if that customer drinks to excess, the fact that the defendant profits should not convert a 'no duty' rule into a

Supra note 2.

[1995] I S.C.R. 131.

I use the term "wealth" in a very broad sense. One person has something that another person needs. Thus, a drunk who is in danger requires someone else to look after or protect him from his own actions. A baby who is drowning requires help from a by-stander, and so on. 
'duty' rule. If applied liberally, the profit rationale would also capture several other defendants in the process, such as the government which licenses and benefits from the sale of liquor, as well as those who manufacture and distribute it. A product liability analysis would not fare much better here, since the liquor which is sold to the customers in these cases is not defective, nor are the dangers which it causes unknown.

A more satisfactory explanation as to why a commercial host should be liable for injuries caused by alcohol consumption is that, unlike a mere by-stander, the provider has through its own negligent conduct in over-serving alcohol in the first instance, placed a victim, i.e. the patron and others, in peril. Having placed those persons in peril by negligent conduct, the provider should be liable for all the foreseeable consequences of that conduct. The duty can be discharged, however, if reasonable conduct is exercised in order to prevent injury from the over-serving. Under this approach, a duty of care will also be owed by the social host who serves alcoholic beverages to guests. Where there will be a difference between the commercial and social hosts, however, is that the standard required from the commercial host to discharge the duty ought to be higher. In determining the standard of care required, factors such as profit, the special skills of the defendant, and statutory responsibilities which govern the activity, could lead to a higher standard of conduct required from the commercial host. This analysis of the commercial and social host liability is consistent with the corrective justice view of tort, while incidentally promoting the laudable public policy goal of preventing accidents caused by alcohol.

The issues raised by the Hall $\mathbf{v}$. Hebert case are similar. Under traditional theory, a by-stander who is aware that an incompetent or a drunk is about to drive away in a car, is under no duty to prevent that person from doing so. This would be true, for example, of all persons in a bar who know that a drunk is about to get into his car and who could with no inconvenience or danger to themselves stop him. Yet Mr. Hebert was under a duty to prevent Mr. Hall from driving his car, even though Mr. Hebert voluntarily initiated the act. Why? What distinguishes Mr. Hebert from the "innocent" by-stander? Was it the fact that Mr. Hebert was the owner or the custodian of the car in question? If this is the answer, one could justifiably question whether it should be tort law that imposes this obligation on owners of cars, as opposed to highway traffic legislation, which ordinarily regulates the obligations attached to car ownership? Perhaps Mr. Hebert owed Mr. Hall this duty because he gave him the keys to the car. If this is so, would a duty be owed to stop Mr. Hall, if he, on his own, took the key and drove off, without any objection from Mr. Hebert? I would suggest that unless one could argue that Mr. Hebert created Mr. Hall's situation of peril, was in a control relationship with respect to him, or fell within one of the other accepted categories where a duty of care is owed with respect to nonfeasances, he should not have been held liable to him.

What is interesting about the majority judgment in Hall v. Hebert is not so much the Supreme Court's conclusion that a duty of care was owed by Mr. Hebert to stop Mr. Hall from driving his car, but that these questions about the source of the duty were not raised. There was an assumption that due to foreseeability of harm, a duty of care was owed. What was overlooked, however, was that in the area of nonfeasance, there is no 
duty despite foreseeability, and that the facts of the case raised a legitimate issue of nonfeasance.

\section{B. THE BREACH OF DUTY ISSUE}

It is clear that the ambiguity of the concept of fault allows courts to compensate victims in situations where reasonable persons might dispute whether sub-standard conduct was truly exhibited by the defendant. Looking at an accident after it has happened, with the benefit of "20/20" hindsight, tends to turn a standard of reasonable care into a standard of perfection.

Inherent in the concept of fault are legal rules which ensure that compensation of victims and not the fault of actors is the law's pressing concern. To the extent that this converts fault based compensation into a system of no fault compensation, one wonders whether it might not be better for tort to be replaced by no fault.

One such rule is the objective standard of care which is imposed upon defendants when it comes down to proving fault. The Alberta case of Wenden v. Trikha ${ }^{49}$ well illustrates the issue. A clearly insane motorist who was labouring under the delusion that his soul was being taken away by a comet and that his car was a time machine was involved in a motor vehicle accident. He was apparently attempting to retrieve his spirit from the spaceship in the sky. In an action brought against him for negligence, psychiatrists testified that the defendant did not understand the nature and quality of his acts, did not understand that he owed a duty of care to others, and if he did was incapable of discharging it. The trial judge accepted this evidence. In such a state of insanity can the defendant be held liable in a fault-based compensation system?

The court found him liable. In coming to this determination, Mr. Justice Murray stated:

[T] he law of negligence is not concerned with punishing the tortfeasor, nor is it concerned with his or her culpability. The concern is one of compensation for those who have suffered loss or damage by reason of the tortious acts of another. The standard used to determine whether or not elements of the tort of negligence are present is the external standard of the reasonable person. . $^{\text {so }}$

In support of his decision, Mr. Justice Murray referred to Lord Justice Denning's decision in White v. White ${ }^{51}$ where Denning L.J. stated that "recent legislative and judicial developments show that the criterion of liability in tort is not so much culpability, but on whom the risk should fall." Mr. Justice Murray also averted to the requirement of mandatory automobile liability insurance as the environment in which tort operates. His Lordship reiterated that: 
[C]ivil courts are not normally concerned with the punitive aspect of the law or one's moral culpability, particularly in this area of tort law. In certain unique circumstances, culpability may become a factor when the facts are such as to warrant punitive damages, but those instances are rare and normally only arise in cases involving an intentional tort, which is not this case. ${ }^{52}$

The no fault debate is not the issue of this article. I will simply make the argument, however, that fault based compensation, without the fault requirement, amounts to no fault compensation. Compensating accident victims from a pool of insurance funds without regard to issues of fault can best be achieved by well structured and well financed no fault schemes, if that is what is deemed to be in the public interest. It cannot be efficiently or economically delivered by the present tort system. What distinguishes tort from no fault is fault. To ignore this is to undermine the integrity of tort.

It is interesting to contrast the standard of care imposed upon the mentally disabled with that imposed upon children. As noted by Mr. Justice Murray in Wenden v. Trikha, although the law does not relax the standard of care for the mentally disabled it does do so for the young. Thus children are not held negligent unless their conduct shows a departure from standards which reasonable children can observe. Although at first blush, this position seems to be at odds with my contention in this article that contemporary tort law is more about compensation than it is about fault, reflection will reveal that in fact this is consistent with that position. Children are invariably plaintiffs in tort law cases, rarely defendants. As plaintiffs, children are subject to the defence of contributory negligence, which if successful will reduce their compensation. The lower standard of care to which children are subject makes it more unlikely that children will be found to be contributorily negligent, and hence more likely that they will be entitled to full, as opposed to reduced, compensation. When, on the other hand, children are defendants, they are frequently involved in what have been called "adult activities." In this case, the adult activities doctrine requires that children live up to the higher standard of care imposed upon adults. Again this helps ensure that plaintiffs, injured by the misconduct of children, will be compensated for their injuries.

\section{THE ISSUE OF CAUSE}

The fact that the defendant's negligence caused the plaintiff's injury is essential to the integrity of fault-based compensation. Corrective justice requires that the defendant repair the harm which he has caused to the plaintiff. ${ }^{53}$ If the defendant is chosen as the source of the plaintiff's compensation not because he harmed the plaintiff, but because he is in the best position to absorb or redistribute the loss, the integrity of tort

52 Supra note 49 at 174 (Alta. Q.B.).

53 As stated by Sopinka J. in Snell v. Farrell (1990), 4 C.C.L.T. (2d) 229 at 242 (S.C.C.):

Causation is an expression of the relationship that must be found to exist between the tortious act of the wrongdoer and the injury to the victim in order to justify compensation of the latter out of the pocket of the former. 
is undermined. The system becomes an inefficient and expensive mechanism to achieve other goals. ${ }^{54}$

In the majority of cases causation is easily proved, on the balance of probabilities, by the "but for" test. The difficulty arises where the plaintiff has proof of the defendant's negligent act, but cannot prove that it was the defendant who "probably" caused the injury. This will arise where there are numerous "possible" causes of the plaintiff's injury, including the defendant's negligent act, but no probable ones. What result is called for in this case by a system of tort which insists upon the causal connection between the defendant's wrongdoing and the plaintiff's injury as a sine qua non of liability?

The desire to compensate a victim, especially where one can find a negligent party who possibly was responsible for the injury, has led to a relaxation of the requirements for proof of causation. The most extreme instance of this came in the English case of McGhee v. National Coal Board..$^{55}$ In this case, the House of Lords held that once the plaintiff has proved that the defendant was negligent, in that his unreasonable conduct materially increased a risk of injury to the plaintiff, the defendant will be held liable for the injury, should it occur. This is so notwithstanding lack of proof that the negligence and the injury were connected as a probability.

Both the House of Lords and the Supreme Court of Canada have backed away from this interpretation of McGhee. ${ }^{56}$ They both, however, have reaffirmed the "spirit" of $M c G h e e$ and the position that proof of causation can be relaxed when justice and the desire to compensate so require. In the Snell case, the Supreme Court of Canada affirmed a judgment holding a medical practitioner liable for his negligence despite the fact that the best the evidence could show was a possible connection between the medical practitioner's negligence and the plaintiff's injury. The judgment was rationalized on the basis that causation need not be determined by "scientific precision," but by regarding both the burden and standard of proof as "flexible concepts." Considering that "in many malpractice cases, the facts lie particularly within the knowledge of the defendant ... very little affirmative evidence on the part of the plaintiff will justify drawing the inference of causation in the absence of evidence to

54 For example, if the goal is to compensate the injured, this can be done without the need to establish that the defendant caused the plaintiff's injury. If the goal is to punish or deter wrongdoing, this can be done without the need to prove that the wrongdoing actually harmed anyone, as long as we are convinced that it is conduct which we want to discourage. If the goal is loss distribution, then no fault compulsory insurance schemes will work best. It is only if the goal is to require a wrongdoer to restore his victim, that cause becomes critical.

ss [1972] 3 All E.R. 1008 (H.L.) [hereinafter McGheen].

s6 Wilsher v. Essex Area Health Authority, [1988] 1 All E.R. 871 (H.L.); Snell v. Farrell (1990), 72 D.L.R. (4th) 289 (S.C.C.). 
the contrary." 57 This "robust and pragmatic approach" to the issue of causation has since been utilized in Canada by lower Courts. ${ }^{\text {s8 }}$

The issue raised by medical malpractice cases where negligence can only be shown to increase a risk of injury, or to diminish the plaintiff's chances of avoiding an injury, has a viable solution which remains faithful to the principle of corrective justice. That solution is to accept the "loss of a chance" thesis. The Quebec case of Laferiere v. Lawson $^{59}$ illustrates the problem. The deceased had a tumour removed from her breast in 1971. Although the tumour was found to have been malignant, the patient was not informed of this and was not advised of the available cancer treatments until 1975. It was then that the patient discovered she had generalized cancer. She died in 1978. In her negligence action against her doctor, continued by her estate after her death, the evidence indicated a problem with proof of causation. Even if the patient had been promptly informed of her cancer, the treatment available at the time did not guarantee, or even make it a probability, that the cancer would be cured. There was only a possible "chance" of cure which the plaintiff had been deprived of due to the defendant's negligence. Could the plaintiff be compensated for this "loss of a chance"?

The Supreme Court decided that she could not. While Gonthier J. supported a generally liberal approach to proof of causation, ${ }^{60}$ he rejected the "loss of a chance" theory. I would suggest that adopting loss of a chance theory, and modifying the damages to accord with the degree of chance involved, would have been a just result in this case. It would fairly attribute to the negligent party the damages consistent with the injury which his negligence caused the plaintiff.

\section{THE DEFENCES}

In Hall v. Hebert, the Supreme Court of Canada firmly closed the door on the defence of illegality, or ex turpi causa, in negligence cases where compensation for personal injuries is the remedy which is being sought. One can also state that the defence of voluntary assumption of risk, while not yet rejected by the Supreme Court, has very little vitality left. It is very rarely used with success, and the judgment in Hall v. Hebert does not bode well for it. Thus, one is now left with only contributory negligence as a viable defence in a negligence action.

Snell, ibid. at 300.

See especially Lankenau v. Dutton (1991), 7 C.C.L.T. (2d) 42 (B.C.C.A.): where it is impossible to say with any certainty whether defendant's negligence made any difference, "a robust and pragmatic approach to the facts" led to liability; Levitt v. Carr, [1992] 4 W.W.R. 160 (B.C.C.A.): open to trial judge to conclude that the defendant's negligence "materially increased the risk" of the injury and that this increase in the risk be treated as a "contributing cause." See also Sigouin v. Wong (1991), 10 C.C.L.T. 236 (B.C.S.C.). (1991), 78 D.L.R. (4th) 609 (S.C.C.).

For example, Gonthier J. reaffirmed that causation in law is not identical to scientific causation, that a causal link can be presumed in cases of clear and present danger, and that statistical evidence need not indicate causation on the balance of probabilities for causation to be found. 
As I have discussed elsewhere, ${ }^{61}$ one element of the judgment in Hall v. Hebert which particularly struck me was the Supreme Court's emphasis on compensation as being the "primary object of the law of torts." While it is true that compensation was semantically linked to the wrongful conduct of the defendant, the judgment contained very little analysis of the defendant's fault, as compared with a heavy stress on the plaintiff's compensation. As indicated above in my discussion of a commercial host's liability, the duty issue in a case involving an allegation that the defendant was negligent for not having prevented the plaintiff from harming himself raises serious jurisprudential concerns. These were all but lost in a judgment which emphasized the compensatory function of contemporary negligence law, and eliminated a defence which occasionally has served as a bar to such compensation.

\section{PURE ECONOMIC LOSSES}

When one considers that it was not until the House of Lord's decision in Hedley Byrne \& Co. v. Heller \& Partners, ${ }^{62}$ that the English common law allowed any recovery at all in tort for negligently inflicted pure economic losses, the development of the economic loss recovery case law, particularly in Canada, must be regarded as one of the most important developments of contemporary tort law. In fact, the retreat by tort from the more familiar accident compensation arenas, might be replaced to a great extent by tort's advances into the economic loss recovery areas, traditionally the domain of contract law.

The Supreme Court of Canada has been very receptive to allowing negligence actions in the economic loss cases. ${ }^{63}$ For the majority of the Court, recovery of purely economic losses poses no particular problems as long as a relationship of sufficient "proximity" exists between the plaintiff and the defendant. There is therefore a general willingness to transplant the justice, compensation, deterrence, and educative goals of accident compensation law into the business setting, as long as this will not create an indeterminate and overly burdensome liability for the defendant. Arguments that economic losses and personal injuries or property damages are qualitatitively different than economic losses and are therefore better handled by efficient business solutions has generally not been received with favour. Thus, the neighbour principle of Donoghue v. Stevenson has entered the law of business, with the understanding that who one's neighbour is has been more closely defined. In one case this resulted in the recovery of damages by a fired employee against his employer in tort, despite the fact that the dismissal was made according to the terms of the agreed upon contract. ${ }^{64}$ In a second case, this resulted in a suit in tort for a misrepresentation which was in essence a breach of a term of the contract. ${ }^{65}$ In a third case, this resulted in a suit in tort for economic losses suffered by the plaintiff as a result of damage to property, which the plaintiff had

(1993), 72 Can. Bar Rev. 553.

[1963] 2 All E.R. 575 (H.L.).

See L.N. Klar, Tort Law, 2d ed. (Scarborough, Ont.: Carswell, 1996) at 171-219.

Queen v. Cognos, [1993] 1 S.C.R. 87: reliance upon a negligent misrepresentation made in the precontractual negotiations was the basis of the recovery.

B.G. Checo v. B.C. Hydro (1993), 14 C.C.L.T. (2d) 233 (S.C.C.). 
a contractual right to use. ${ }^{66}$ In a fourth case, this resulted in a suit in tort for economic losses suffered by the owner of a building due to the allegedly negligent construction of the building by a non-privity builder. ${ }^{67}$

One might suggest three approaches to the use of fault-based tort in cases such as these. The first would be to apply negligence law to economic loss cases subject to traditional concerns for reasonably limiting a defendant's liability by special rules of proximity. For the most part, this has been the approach of the Supreme Court. The second approach would be to refuse to apply fault-based tort to cases where the parties did, or could have, allocated risks of economic losses through contract. This, in my opinion, would have denied the plaintiffs' tort recovery in all four cases noted above. The third approach would be to allow the courts to accept economic arguments to determine the most efficient allocation of responsibility in the case before it. This could result in either liability or a denial of liability. Mr. Justice La Forest, as noted above, is a proponent of this approach. He therefore would have dismissed the plaintiff's action in C.N.R. v. Norsk, and London Drugs v. Kuehne, Nagel, ${ }^{68}$ but upheld the plaintiff's right to sue in tort in Winnipeg Condominium v. Bird Construction. The interesting aspect of Mr. Justice La Forest's approach is that he concedes that fault should not be the criterion for liability in these cases, and that evidence of the economic arguments, such as the availability and cost of insurance, ought to be considered.

Despite my general enthusiasm with respect to tort and the importance of fault, the pure economic loss area may be the one area where economic arguments ought to prevail in deciding how to allocate losses arising from negligent conduct. As explained by Professor Feldthusen, ${ }^{69}$ economic losses, especially those arising in the business context, are qualitatively different from personal injuries, or property damage, arising from accidents. Issues of justice, accident prevention, safety, and compensation which are the foremost concerns in accident cases, are replaced by efficient loss allocation concerns in the business cases. If insurance, or contract, can more efficiently allocate business losses than can tort, there is much to be said for leaving dispute resolution in these instances to those regimes.

\section{CONCLUSION}

Fault based compensation is based upon notions of personal responsibility and accountability for injuries which one causes to another. When this focus is replaced by the desire to compensate accident victims by redistributing the costs of accidents via insurance, fault based tort loses its relevance. Separated from its fundamental premise of corrective justice, tort law becomes an inefficient and expensive way to provide for the needs of accident victims. Courts ought to resist the understandable temptation to

\& C.N.R. v. Norsk, [1992] I S.C.R. 1021.

o7 Winnipeg Condominium Corp. v. Bird Construction, [1995] I S.C.R. 85.

6s Supra note 11 .

69 B. Feldthusen, Economic Negligence: The Recovery of Pure Economic Loss, 3d ed. (Scarborough, Ont.: Carswell, 1994). 
convert fault into no fault. Courts must continue, however, to formulate laws which deal with issues of civil justice, the consequences of wrongdoing, the protection of individual security and dignity, and the civilized regulation of human conflict. Gaps or deficiencies in the community's responsibility to care for the needs of the disabled or disadvantaged will be revealed, and sensible legislative programs can be devised to respond properly to them. 